\title{
Polymorphic microsatellite loci in the endangered butterfly Lycaena helle (Lepidoptera: Lycaenidae)
}

\author{
Jan Christian HABEL ${ }^{1}$, Aline FINGER ${ }^{2}$, Marc MEYER ${ }^{1}$, Thomas SCHMITT $^{2}$ and Thorsten ASSMANN ${ }^{3}$ \\ ${ }^{1}$ Musée National d'Histoire Naturelle, Section Zoologie des Invertébrés, 25, rue Münster, L-2160 Luxembourg; \\ e-mail: Janchristianhabel@gmx.de \\ ${ }^{2}$ Biogeographie, Universität Trier, D-54296 Trier, Germany \\ ${ }^{3}$ Leuphana Universität Lüneburg, Institut für Ökologie und Umweltchemie, D-21335 Lüneburg, Germany
}

Key words. Lepidoptera, Lycaenidae, Lycaena helle, microsatellite marker

\begin{abstract}
Six polymorphic microsatellite loci were isolated in the endangered butterfly Lycaena helle. Five of them provided interpretable results. We detected four to 34 alleles per locus in a total of 235 samples (males and females) collected from meadows in the Ardennes-Eifel (Germany, Luxemburg and Belgium) and the Westerwald (Germany). We collected one leg for DNA-extraction as a non-lethal method. The expected heterozygosities ranged from $48.6 \%$ to $83.1 \%$, depending on the locus analysed. These markers are currently being used in our studies of the species' phylogeography over its western Palearctic distribution area and for the analysis of the conservation status of the fragmented populations in Central Europe.
\end{abstract}

Lycaena helle (Denis \& Schiffermüller, 1975) is a species with a boreo-mountainous distribution (Ebert \& Rennwald, 1991; Tolman \& Lewington, 1997; Kudrna, 2002). During the early postglacial, this lycaenid butterfly may have been homogenously distributed over major parts of the western Palearctic. Climatic changes over the past thousands of years have led to a disjunct distribution scattered over parts of Scandinavia and the European mountain systems (e.g. Pyrenees, Alps, and Carpathians). Habitats of Lycaena helle are characterised by a moisty character and cool climate. Anthropogenic land use changes (e.g. agricultural intensification, afforestation of nonwooded habitats) combined with climate changes have resulted in the extinction of this species in many parts of Central Europe (Fischer et al., 1999). Sites still colonized by Lycaena helle are mostly scattered over regions of higher altitude (e.g. in Central Europe the Massif Central, Vosges, Ardennes, Eifel, Westerwald). These sites are often isolated and most probably represent small remnants of ancient population networks. All these factors enforce the collapse of interconnected habitat networks (IUCN, 1996; Van Swaay \& Warren, 1999).

With the aid of microsatellite markers we analysed the phylogeography and the genetic status of this disjunctly distributed species with its extant metapopulations in the Alps and isolated and small relict populations in Central Europe (cf. Luikart et al., 1998).

Six recombinant clones were randomly selected from a microsatellite enriched library (Gruenstein \& Hogness, 1975; Hamilton et al., 1999) for sequencing analysis, and PCR primers were designed for six loci. One microsatellite locus (Lhe13) was abandoned because of problems during the optimization of the PCR amplification process.

Polymorphism of five PCR-primers generating the expected PCR products was tested with 235 Lycaena helle samples collected from different sites in the Ardennes, the Eifel and the Westerwald. DNA was extracted from individuals using a Qiagen DNeasy ${ }^{\mathrm{TM}}$ Tissue Extraction Kit (Hilden, Germany).

TABLE 1. Characteristics of six polymorphic microsatellite loci in Lycaena helle. Abbreviations: $\mathrm{F}$ - forward primer; $\mathrm{R}$ - reverse primer; $\mathrm{T}_{a}$ - annealing temperature; $A$ - mean number of alleles; $H_{\mathrm{o}}-$ observed heterozygosity; $H_{\mathrm{e}}-$ expected heterozygosity; 235 individuals were analysed for each locus.

\begin{tabular}{|c|c|c|c|c|c|c|c|c|}
\hline Locus & $\begin{array}{c}\text { GenBank } \\
\text { Accession no. }\end{array}$ & Primer sequence $\left(5^{\prime}-3^{\prime}\right)$ & $\begin{array}{c}\text { Repeat } \\
\text { motif }\end{array}$ & $\begin{array}{l}\text { Size of sequenced } \\
\text { allele (bp) }\end{array}$ & $\mathrm{T}_{a}\left({ }^{\circ} \mathrm{C}\right)$ & $A$ & $H_{\mathrm{o}}$ & $H_{\mathrm{e}}$ \\
\hline Lhe03 & EU117181 & $\begin{array}{l}\text { F: GCGCAAACTATTCAGTTTAC } \\
\text { R: ACTTAAATGTTTCTCGGCTC }\end{array}$ & $(\mathrm{GACA})_{5}$ & 271 & 53 & 4 & 54.2 & 48.6 \\
\hline Lhe13 & EU117182 & $\begin{array}{l}\text { F: ACTTTTGGTGATCTCTTAAG } \\
\text { R: AACATAATGGTTTGCCGCTG }\end{array}$ & $(\mathrm{CA})_{15}$ & 299 & 55 & - & - & - \\
\hline Lhe14 & EU117183 & $\begin{array}{l}\text { F: GTTGTTTTCGAGCCAAGGAG } \\
\text { R: AGTGACGATTCCGATGACTC }\end{array}$ & $(\mathrm{AT})_{18}$ & 281 & 56 & 26 & 55.3 & 83.1 \\
\hline LheB06 & EU117178 & $\begin{array}{l}\text { F: CCTTTCCACATATAGTTGGC } \\
\text { R: CATCGTCAGGTCACTTCATC }\end{array}$ & $(\mathrm{TA})_{8}$ & 486 & 54 & 28 & 52.5 & 78.0 \\
\hline LheE12 & EU117179 & $\begin{array}{l}\text { F: AAATCAAGTCACGCATAC } \\
\text { R: CCTTAATCGATGGCAATTTC }\end{array}$ & $(\mathrm{TG})_{26}$ & 448 & 53 & 13 & 78.8 & 73.8 \\
\hline LheF12 & EU117180 & $\begin{array}{l}\text { F: AGTAGCCATTTTACCGTCAG } \\
\text { R: CTACGCAACGGATTTTGATG }\end{array}$ & $(\mathrm{GT})_{24}$ & 401 & 54 & 34 & 68.5 & 72.1 \\
\hline
\end{tabular}


Microsatellite loci were amplified in a reaction mixture of Thermozym Mastermix (Molzym, Bremen, Germany) and about 20-100 ng diluted DNA, depending on the locus analysed. To reduce costs and laboratory work, two microsatellite markers were multiplexed. The multiplex contained two pairs of primers, Lhe03 and LheE12 loci were amplified. The loci LheF12, LheB06, and LheE14 were amplified separately. The PCR amplifications were performed in a total of $27.6 \mu \mathrm{l}$ for the multiplex which contained $25 \mu 1$ Thermozym Mastermix, 3 pmol for each primer of the Lhe 03 locus and 10 pmol for each primer of the LheE12 locus. For LheF12, LheB06, and LheE14 a total of $16 \mu \mathrm{l}$ contained $10 \mu \mathrm{l}$ Mastermix and 5 pmol for each primer. Amplification was initiated with 1 min of denaturation at $94^{\circ} \mathrm{C}$ followed by 45 cycles involving $30 \mathrm{~s}$ of denaturation at $94^{\circ} \mathrm{C}$, $30 \mathrm{~s}$ of primer annealing at a temperature ranging from 53 to $56^{\circ} \mathrm{C}\left(T_{a}^{\circ} \mathrm{C}\right)$ and $1 \mathrm{~min}$ of extension at $72^{\circ} \mathrm{C}$, and a final extension step at $72^{\circ} \mathrm{C}$ for 2 min following a cool down to room temperature (see Table 1). $10 \mu 1$ of the PCR products were loaded and PCR fragments resolved by electrophoresis on $2.4 \%$ agarose gels stained with ethidium bromide as a control before scoring the microsatellites using an automated sequencer running Megabace software (GE Healthcare, USA).

Significant deviations from Hardy-Weinberg equilibrium $(p<$ $0.05)$ were detected for two of these loci. With the program Micro-checker (van Oosterhout et al., 2004) we found strong evidence for null alleles for the loci Lhe B06 and Lhe E14. No significant linkage disequilibrium was detected among any two loci $(p>0.05)$. The total number of alleles ranged from four to 34 per locus with a total value of 105 alleles detected over all populations. The expected heterozygosity averages over all populations analysed for the five loci ranged from $48.6 \%$ to $83.1 \%$ (Table 1). The expected and observed heterozygosity for these loci was calculated using GenAlEX (Peakall \& Smouse, 2006).

ACKNOWLEDGEMENTS. We acknowledge a grant from the Ministère de la Culture, de l'Enseignement Supérieur et de la Recherche, Luxembourg (grant number BFR05/118) and the Musée National d'Histoire Naturelle Luxembourg which funded this study. We thank F. Zachos for useful comments and D.
Kime (La Chapelle-Montmoreau, France) for the English correction.

\section{REFERENCES}

Ebert G. \& Rennwald E. (ed.) 1991: Die Schmetterlinge Baden-Württembergs. Vol. 1. Eugen Ulmer, Stuttgart, 552 pp.

Fischer K., Beinlich B. \& Plachter H. 1999: Population structure, mobility and habitat preferences of the violet copper Lycaena helle (Lepidoptera: Lycaenidae) in Western Germany: implications for conservation. J. Conserv. 3: 43-52.

GruensteIn M. \& HoGNeSS D.S. 1975: Colony hybridization. Method for the isolation of cloned DNA's that contain a specific gene. Proc. Natl. Acad. Sci. 72: 3961-3965.

Hamilton M.B., Pincus E.L., Di Fiore A. \& Fleischer R.C. 1999: Universal linker and ligation procedures for construction of genomic DNA libraries enriched for microsatellites. Biotechniques. 27: 500-507.

IUCN 1996: The 1996 IUCN Red List of Threatened Animals. IUCN Publications Service Unit, Cambridge, $341 \mathrm{pp}$.

KudRnA O. 2002: The distribution atlas of European butterflies. Oedippus 20: 1-342.

Luikart G., Sherwin W.B., Steele B.M. \& Allendorf F.W. 1998: Usefulness of molecular markers for detecting population bottlenecks via monitoring genetic change. Mol. Ecol. 7: 963-974.

Oosterhout C. van, Hutchinson W.F., Wills D.P.M., Shipley P. 2004: Micro-checker: Software for identifying and correcting genotyping errors in microsatellite data. Mol. Ecol. Not. 4: 535-538.

Peakall R. \& Smouse P.E. 2006: GENEALEX 6: Genetic analysis in Excel. Population genetic software for teaching and research. Mol. Ecol. Notes 6: 288-295.

van Swayy C.A.M. \& Warren M. 1999: Red Data Book of European Butterflies (Rhopalocera). Nature and Environment 99, Council of Europe Publishing, Strasbourg, 264 pp.

Tolman T. \& Lewington R. 1997: Field Guide Butterflies of Britain and Europe. Harper Collins, London, 384 pp.

Received June 15, 2007; revised and accepted January 21, 2008 